\title{
Determination in the District Area Galunggung Sukaratu as Strategic Areas Amusement
}

\author{
Dr. Thomas Bustomi \\ Chairman of the Public Policy Program graduate studies Pasundan of University
}

Received: August 21, 2016 Accepted: September 25, 2016 Published: September 27, 2016

doi: 10.5296/jsss.v4i1.10079 URL: http://dx.doi.org/10.5296/jsss.v4i1.10079

\begin{abstract}
This study entitled "Determining Region Galunggung in District Sukaratu As Strategic Area Nature". The purpose of this policy is to increase the activity of the business world in the tourism sector in KGG - KS so as to improve the regional economic growth both on a district or on a regional scale Tasikmalaya regency. The method used in this research is action research (action research) using a qualitative approach. Results of the study were divided into four categories: problem identification, determination of the terms of problem solving, determination of alternative policy formulation and determination of the alternative selected as the end result of this policy formulation. Official data are not obtained, shall be carried out exploration data / information through other means in order to identify the problems become whole / full. In this research, a lack of data / information that is experienced by the researchers can be overcome because there is input from the community although its accuracy is lower. Meanwhile, the establishment of technical provisions troubleshooting is done based on a reference from the rules of the policy object. Each process / stages of policy formulation are not always able to generate a specific output. Determination of the technical provisions of Resolution "or the theory of public policy referred to as" the evaluation criteria Resolution "is one very important part in the process of policy formulation.
\end{abstract}

Keywords: Determination, District, Strategic, Amusement

\section{Preliminary}

Galunggung with a summit elevation of 2,168 meters above sea level is one of the volcanoes in Java are still active. Galunggung were in two districts, namely the western side was included in the district of Garut, and the east side was included in the district of Tasikmalaya. Galunggung had erupted enormously 4 times, namely in 1822, 1894, 1918 and 1982. The eruptions have left a large crater that is now turned into a beautiful lake with an island in the middle, which is named Crater Lake Galunggung, Stories of the terrors of the eruption of Mount Galunggung invite curiosity of people to visit there for a tour. Galunggung save 


\section{MInstitute ${ }^{\text {Mink }}$}

magma causes the springs originating from Mount Galunggung have warm to hot temperatures, the condition is exploited by the private sector into a hot water bath. Tourist area of Mount Galunggung quite bring in more tourists though not develop optimally and yet provide konstibusi significantly to the economy and welfare of local communities. Crater Lake area Galunggung and water baths arrows can be seen as an embryo that is promising for the development of eco-tourism in the District Sukaratu.

Related to this potential, Tasikmalaya District Government has issued policy such determination Galunggung in District Region Sukaratu as Strategic Regions Nature. Zone pricing policies Galunggung District of Sukaratu (hereinafter abbreviated as KGG - KS) as Stratagis Region Nature is manifested in Tasimalaya District Regulation No. 2 of 2012 on Spatial Planning (RTRW) 2011-2031 Tasikmalaya regency Article 49 which states that " region Galunggung developed into a Strategic Regional Nature's economic interests ". Then clarified in Article 56 that "Regions Galunggung developed into a strategic importance in the District Nature Sukaratu.

To realize KGG - KS as a natural tourism area that can grow the regional economy, regional development in the region KGG - KS should be focused on the tourism sector as a sector basis (base sector). One of the regional development concepts commonly used in rural areas is the concept of regional development. According Djakapermana (2010: 7) The development area has basically the goal of keeping the region's progress towards the desired level of development. The development of the area carried out by optimizing the utilization of its available resources in harmony, harmonious and integrated through a comprehensive approach that includes aspects of physical, economic, social, cultural, and environment for sustainable development.

Related to the development efforts KGG - KS, then the various resources in KGG - KS in particular, both of Natural Resources (SDA), Human Resources (HR), and institutional, should need to be explored and developed in harmony, harmonious and unified. Nature tourism sector in KGG - KS face obstacles developments that one of them caused by the activities of the mining sector is sand mining. Nature tourism activities are activities that are highly dependent on natural conditions are maintained so as to give / create the values of beauty, comfort, and pleasure. But otherwise, mining activities synonymous with activity sufficient "hard" and away from the values of beauty.

Judging from the institutional, it can be said that the current KGG - KS are within two authorities, namely the forest areas under the jurisdiction of Perum Perhutani units III Tasikmalaya state-owned property of the Government $(\mathrm{MoF})$ and other areas are under the authority of the District Government Tasikmalaya. In realizing KGG - KS as a strategic area of nature through the development efforts of the region to be done very carefully through a process of careful planning, good planning technical nature / physical as well as planning the non- technical (administrative). The completion of the Regional Development Plan for the region will facilitate the decision-makers in directing development activities in the area concerned. The initial step of Tasikmalaya Regency Regional Regulation No. 2 of 2012 is conducting the preparation of Regional Development Plans KGG - KS.

In the context of public administration, regional development planning is a form of public policy, because the result is for the public. According to Dunn (1999: 24) the preparation of a 
policy carried out through several phases, in sequence, namely agenda-setting, policy formulation, policy adoption, policy implementation and policy assessment. Based on this background, the question that then arises is how to formulate policies for regional development KGG - KS in order to obtain an efficient policy decision that could shape the future KGG - KS desirable that as a Strategic Area Nature in order to grow the regional economy.

\section{Method}

This study was included in the category of action research (action research). According Rusidi in Satibi (2011: 81), action research aims to improve an area / areas (including community life) soon after the research is done. In connection with that researchers are exploring the object of research as possible to obtain a complete picture of the object to be examined and ends by concluding an invention (induction) which then must be followed. The approach taken is a qualitative approach. The success of a study with a qualitative approach, among others, is strongly influenced by the completeness, accuracy of data / information obtained in the field. Thus the researchers will collect data / information in two ways, namely the collection of primary data and secondary data collection.

In the study, the analysis is done by processing data / information that could explain the problems studied and / or give direction to the solution of problems faced. The analysis in this study was conducted in three stages, namely data analysis, analysis of alternatives determination of policy formulation and analysis of alternative selection policy formulation. Analysis of the data include: (1) the analysis of natural resources and artificial resources, (2) analysis of human resources. Analysis of alternative policy formulation determination carried through two stages. The analysis carried out to assess the stage of unity throughout the local conditions, namely the potential, constraints, opportunities, and threats together (holistic) using the method of SWOT (Strength, Weakness, Opportunity and Threats). Phase 2 is the involvement of the public to determine the number of alternative policy formulation desired direction. Phase determination of alternative policy formulation is done by combining "technical provisions" of regional development KGG - KS anallisis results from phase 2 to the typology of public aspirations in a way that is expected to generate a number of alternatives for the development of the region KGG - KS.

Analysis of alternative selection policy formulation aimed to choose the alternative that is considered the most efficient that can be accepted by all parties concerned. This analysis is done through a process of assessment of the advantages and disadvantages of each alternative policy formulations have been previously defined. According Sujarto (2008), assessment of alternative policy formulations made using several criteria assessors, namely: (1) effectiveness, (2) efficiency, (3) Sufficiency, (4) alignment, (5) Responsiveness, and (6) Eligibility, as a complement, analysis formulation of these policies should be accompanied by institutional analysis as a principal policy implementation. Institutional analysis done by considering three aspects, namely: (1) Alternative, (2) existing institutional conditions, and (3) public aspiration. This study is limited only to the election of regional development policy formulation KGG-KS and not up to the preparation of policy implementation. 


\section{Results and Discussion}

The results of the research presented in this chapter is the result of the whole process of preparing the Regional Development Policy KGG-KS as a Nature Area on the theory of public policy formulation. Broadly speaking, as has been explained before that the formulation process of regional development KGG-KS consists of the following stages: (1) Identify the problem, (2) Determination of the provisions of solving the problem, (3) Determination of alternative policy formulation and (4) Determination of the alternative selected as the end result of policy formulation.

Identification of problems is the earliest stage in the process of policy formulation (Nugroho, 2008) so that the successful formulation of policies one of which is determined by keberhasilaan identify the problem. Here is a description of the identification of the problem:

1) KGG-KS has a number of potential areas (factor of the power / strength) that have not been optimized, namely: (a) Physical condition: in KGG-KS are appreciating natural potential travel sales, the Crater Lake Galunggung, hot springs, and panorama beautiful (b) the use of land; Land in the area KGG-KS fertile and has the potential to be developed into agricultural land intensive and multibenefit. The proportion of the area woke up still relatively low, meaning that the carrying capacity of the land for the physical development is still large (c) Population: The existence of social values Sunda and religious values were very strong, which could serve as a catalyst for tourism development activities dignified. The existence of public figures in KGG-KS respectable that may be involved in regional development programs to increase the participation of citizens / communities. Already the growth of secondary sector, namely industrial activity and trade-services performed by the local community that can be used to promote tourism activities. Their potential economic crops such as agricultural commodities, particularly grain and fishing good fish and ornamental fish consumption to support tourism activities. Their tourism activity has grown, which is a tourist attraction Crater Lake Galunggung and Hot Water Cipanas which can be used as an embryo for the development of tourism in the future (d) infrastructures: Availability of the road network is fairly evenly distributed to serve the movement of the external and internal, but the condition of the road still not good. The potential source of abundant water is sourced from springs in the Mount Galunggung, but has not been used optimally. Already tersedinya electric utilities and energy, but has not yet reached to the entire area to be developed. The availability of an adequate number of cell towers for wireless connection, but there are still areas blackspot (loss of signal).

2) KGG-KS has a number of conditions that may hinder the process of regional development (factor of weakness / weakness), namely: (a) Physical condition: Some regions KGG-KS has a slope of over $15 \%$. The slope is an obstacle to the development / regional development awakened. The whole area of KGG-KS included in an area prone to the eruption of Mount Galunggung so this is a limiting factor in regional development. Their mining activities excavation $\mathrm{C}$ (sand) in the village of Sinagar and Village Linggajati which raises a certain number of environmental disturbance, namely a decrease in air quality, reduction in surface water quality, decreased quality of roads (b) Population: Lower education levels, local communities will impede and complicate the development process because the quality of 
human resources that are less supportive. Their development investments that are less involve the community so that people can not enjoy the fruits of development (c) infrastructures: The low quality of the road network in particular that led to the location of a tourist attraction existing will hamper economic activities including tourism activities, unavailability of sub terminal, there is not yet public transit to serve internal movement, lack of clean water network managed by the government so that the supply, distribution, and management of clean water is difficult to control, then the pattern of the population is still traditional processing waste in a manner piled, burned and thrown into the river. Such management has a number of disadvantages such as causing pollution and disease vectors and the absence of polling stations across the region, will degrade the quality of the environment (d) Facilities / Amenities: Unavailability of market and commercial center, will complicate the mechanism of the local economy, especially in tourism activity mendukunng. The absence of vocational schools that support the development of tourism.

3) KGG-KS had a number of chances / opportunities (factors chance / opportunity) that can be used to support regional development KGG-KS, such as: (a) Physical Condition of Natural History Galunggung: History of the eruption of Mount Galunggung very terrible make Mountain Regions Galunggung became famous and has become a local tourist destination, so the opportunity to develop the market scale regional / national (b) geographic: KGG-KS geographically well-positioned strategically and not too far from Tasikmalaya and urban areas Singaparna which is the Capital District Tasikmalaya which has a number of urban facilities. Attractions existing in KGG-KS only $5 \mathrm{Km}$ to the primary collector Cisinga (Singaparna-Ciawi) and, subsequently, less than $10 \mathrm{~km}$ to the primary arterial road Bandung Tasikmalaya either through cross Malangbong - Tasimalaya or through cross outlining Tasikmalaya (c) Supporting Tourism Economic Activity: bamboo craft center in the District Rajapolah, located about $15 \mathrm{~km}$ from KSK Galunggung and embroidery centers in the districts around in the district of Tasikmalaya and District Panjalu. Its presence can be used to support regional development KGG-KS. Destination Region (DTW) is varied, such as Pangandaran Beach, Bamboo Craft Center Rajapolah, Embroidery Craft Center Tasikmalaya, Garut nature, etc.

4) KGG-KS has a number of conditions that could threaten the development of the region of interest (factor of threat / threat), namely: (a) Physical Condition of Natural History Galunggung as a volcano: KGG-KS is an area prone to the eruption of the volcano (b) Geographic: region KGG-KS is the hinterland of the city Singaparna and Tasikmalaya thus influence the development of the city is a territory runoff growth (expansion and invasion) from both the city and would like to invest in the future, so it is feared could threaten the existence of travel natural.

The provisions of solving the problem of regional development KGG-KS that must be followed, based on the combination of strength (strength), weakness (Weakness), opportunity (opportunity), and threats (theath) in table SWOT analysis can be seen in Table 4.1 below. 
Table 1. Provisions technical problem solving KG-KS-Based regional nature

1) Purpose : The need to perform a thorough development (whole).

2) Development of : (a) The need to develop the natural potential that is nature-based economic worth selling travel into a tourist destination (DTW) and activities. connected to DTW in the external area through co-management.

(b) The need for the development of other sectors through intensification once developed into and / or support the activities of travel.

(c) The need for the development potential of the area more "marketable travel" in the area that became the target of invasion targeted residential sector.

3) Development of basic : Need for increased transportation infrastructure, water infrastructure resources infrastructure, telecommunications infrastructure, solid waste infrastructure.

4) Improvement and : The need for infrastructure improvement / education development of facilities, health facilities, economic facilities. infrastructure / facilities

5) Protecting the : (a) The need pendelineasian protect areas that have environment character, both to protect the area underneath and protect locally.

(b) The need for the maintenance of components of the environment to support sustainable development.

(c) The need for physical development planning tailored to the prediction of the possible time back eruption of Mount Galunggung.

6) Institutional : The need for the use of the presence of community leaders Development to mobilize communities capture the opportunities that exist to develop KGG-KS.

Source: The results of our analysis, 2013.

Aspiration meaning for the Determination of Alternative Public Policy Formulation Development Areas KGG-KS. The condition of public aspirations towards development of the region KGG-KS-based tourism are as follows:

1) Public consist of four groups, namely the bureaucrats at the top level (District Government Tasikmalaya), a group of bureaucrats at lower secondary level (sub-district and village), citizens 'groups / communities, and employers' groups.

2) Aspects of the answers can be grouped in six aspects in accordance with the pillars of regional development / development of the region, namely the aspect of purpose, the economic 


\section{Ml Macrothink}

development aspects, aspects of basic infrastructure, means // aspects of social facilities, environmental aspects, and aspects of management-institutional / institution.

3) Each group has a tendency public interest in a particular aspect or a combination of some aspects differently, namely: (a) group of bureaucrats at the top level (the District Government of Tasikmalaya): tend to appreciate aspects of basic infrastructure and environmental aspects of the issue; (b) Group bureaucrats at lower secondary level (sub-district and village): tend to appreciate aspects of the development of economic activities and aspects of basic infrastructure; (c) Group of people / communities: They tend to appreciate aspects of the destination and development aspects of economic activity, (d) Group of entrepreneurs: They tend to appreciate aspects of the development of economic activities, aspects of basic infrastructure, and institutional aspects of co-management / institution. One of the aspirations of a group of businessmen and even tend to ignore rules and regulations, where it was said by PT. Perhutani found that PT. Perhutani has permission to open a new road network which penetrates the forest area in order to develop a tourist area that is managed by a private pengisaha in the outside of the forest area. But in fact such consent not being disclosed to the investigators.

4) Each of aspiration in every aspect quite diverse but still can be patterned. Even so, overall, we can say that the whole of aspiration in every aspect of the meaning of "supporting" the efforts of regional development KGG-KS-based nature, and only sediit there are differences in viewpoints that interpret and express their aspirations.

5) One very important thing is that no finding of aspiration extreme patterns in each group leading to the aspirations of the whole which involves all aspects of the development of the region KGG-KS.

In general the public aspirations of all four groups of respondents is the same, namely the support of regional development KGG-KS-based tourism, it's just that there are differences of emphasis interest of each public groups associated with the background group, and there are variations of aspiration in every aspect that could generally be said to be contradictory.

Due to the conditions of public aspirations are not extreme in each group of the public, then in this case the researchers conclude that public aspirations captured in this study did not show the public desire diverse so it can not bring variation alternative formulation of policies for regional development for KGG-KS based on nature. Public aspirations sticking to the surface tends se "meaning" that supports pengembaangan KGG-KS area-based nature tourism by taking into account the interests of society, develop local potential, develop basic infrastructure, care for the environment, and carried through the management and coordination. In other words, one of the stages of policy formulation disclosed by Nugroho (2008), namely the establishment of alternative policy formulation stage, does not occur in this study.

However, researchers consider this aspiration can still be used as inputs in the process of policy formulation at a later stage, to the extent not in conflict with the technical provisions as already produced a SWOT analysis that has been done or is contrary to applicable legislation.

Determination of policy formulation is the fourth stage in the process of defining policy formulation in this study. Ideally the determination of policy formulation is done through the 
process of selecting an alternative that is considered the most efficient / appropriate to be applied, where alternatives are raised should come from public aspirations. Here is a description of each strategy on policy pengemmbangan KGG-KS area.

1) The purpose of the development of areas, the development KGG-KS is "to enable KGG-KS area as the area developed and supported by the tourism sector to achieve a prosperous community life, cultured (civilized), and sustainable".

2) Economic Activity Development Policy, developed through several strategies, namely, (a) Developing the potential of existing natural attractions such as craters, waterfalls (waterfall), panorama, cool air into an optimal tourism activities; (b) Develop sector through diversification of existing activities that can double as a tourist attraction; (c) Exploring and developing new tourist activities. Developing tourism support activities; (d) Integrate tourism Galunggung with attractions nearby; (e) Integrate tourism Galunggung with attractions nearby; (f) Utilize land-Lahn ex-mining (quarry); and (g) Limiting activities that do not support tourism activities.

3) Basic Infrastructure Development Policy through transportation infrastructure diantaraya: (a) Improve the quality of the existing road network in a hierarchical manner; (b) Building a new road network in accordance with applicable regulations in locations that are considered necessary in order to support the development of tourism; (c) Develop public transport. Policy development infrastructures Water Resources include: (a) Optimization of available water resources, nor the development of new and (b) Development of the network of clean water sources. Electricity infrastructure development policies and Energy, among others: (a) The utilization of electrical energy sources and (b) Improving energy services in addition to electricity. Telecommunications infrastructure development policies, namely improvement wired or wireless telecommunications network. Policy development working paper waste by building solid waste infrastructure. Sanitary infrastructure development policies, namely the development of individual septic tanks in the area woke up.

4) Facilities Development Policy / Social amenities, including: (a) Improving social service facilities that already exist and (b) Establish new social facilities.

5) Environmental Policy, among others: (a) Maintain the area to be protected; (b) Development based on adaptive to the eruption of the mountain and (c) performs the prevention of pollution of water and air pollution.

6) Policy-management of institutional / institutions, among others: (a) Establish a team of business-KS Tourism KGG and (b) Increasing public awareness to conduct business activities oriented to the tourism sector.

Implementation of programs and development activities that are physical in order to develop region-KS KGG aforementioned format into the spatial / space. Elaboration of regional development policy formulation KGG-KS into spatial format include: (1) Tutorial macro nature tourism development; (2) Referral space utilization; (3) The directives of basic infrastructure development, and (4) Tutorial facility development / social facilities.

At the stage of identification of the problem, researchers have difficulty in collecting data KGG-KS existing conditions in full. The reason is because not all required data has been available secondary data, ie data on potential water resources, environmental quality data, 
and data protection forest. Though to produce good policy, it first must be identified properly permasaahan (Nugroho, 2008). These limitations do not significantly affect selanjutya stage, namely when the determination of the technical provisions solving problems.

At this stage of the establishment of technical provisions for regional development problem solving, researchers using SWOT analysis. SWOT analysis in this study also did not issue / conclusion grades usually show a value position in the quadrant I or quadrant quadrant II or III or IV quadrant. Instead, the researchers conducted a qualitative analysis by combining Strength - Opportunity, Weakness - Opportunity, Strength - Threat and Weakness -Threat. The result is in the form of a number of provisions that should be taken in the framework of regional development KGG-KS.

At the stage of identification of the public desires associated Regional Development KGG-KS, researchers found some of the following: (1) The number of respondents did not have to follow the rules of sampling with specific proportions that are considered representative, but more emphasis on completeness and diversity of information required is deemed to have been sufficient for analysis; (2) Each group of respondents have interes (focus replies) special / specific to the background and interests, although in some parts there is common interest (the focus of answers); (3) The question is open to the respondent consequences answers are very diverse, so it should be grouped in advance so easy to be analyzed; and (4) The researchers found that none of the group of respondents who gave their aspirations intact for all aspects of the pillars of development, so that researchers could not formulate an aspiration for Regional Development KGG-KS intact from each group public.

At this stage of the formulation of development policy Regional Development KGG-KS, the investigators failed to stage the selection of alternative policy prescriptions for the public's aspirations did not raise aspirations intact. Thus the researchers conducted policy formulation Regional Development KGG-KS by means of structuring the entire public aspiration for all aspects with reference to the technical provisions troubleshooting predetermined.

\section{Conclusions and Recommendations}

\subsection{Conclusions}

1) The official data is not obtained, it should be carried out exploration data / information through other means in order to identify the problems become whole / full. In this research, a lack of data / information that is experienced by the researchers can be overcome because there is input from the community although its accuracy is lower. Meanwhile, the establishment of technical provisions troubleshooting is done based on a reference from the rules of the policy object.

2) Identification of the public desires through group method can not always be led to the formulation of policy alternatives are varied, so that attract researchers hypothesize that each process / formulation stage of the policy are not always able to produce a specific output.

3) Formulation of the policy carried out by combining (combaining) between public desires with reference to the provisions of solving technical problems that have been set in the previous stage. Determination of the technical provisions of Resolution "or the theory of public policy referred to as" the evaluation criteria Resolution "is one very important part in the process of policy formulation, 


\subsection{Recommendations}

1) Identify the problem should be done as possible so there is no problem related to remaining and missed as consideration in policy formulation.

2) Determination of technical provisions as an evaluation criterion problem solving problem solving, should refer to the rules of the policy object.

3) The formulation of public policy should be conducted in stages, starting from the formulation of policies that are strategic to more detailed policy.

4) Mechanical aspiration must be done carefully so that the public can give the right answer, sharp, and independent.

5) When the setting process of policy formulation can not be done by selecting a number of alternatives, there should be another reference that can be used to compare the desired formulation of public policy. A reference which is considered the most according to the researchers are the rules of the policy object.

6) This study should be complemented by other research to formulate policies related to management form KGG-KS, given the region there are several parties involved, namely the District Government Tasikmalaya, Tasikmalaya Perum Perhutani III unit, and society.

7) The formulation of policies for regional development KGG-KS generated from this study should be followed by ratification and elaboration of policies in the form of program planning and development activities that require separate analysis

\section{References}

Agustino, L. (2006). Political and pubic policy. Bandung: AIPI Bandung - Puslit KP2W. Bratakusumah, D. S. (2003). Regional Planning. Jakarta: PT. Gramedia Pustaka Utama Danim, S. (2005). Introduction to the Study of Policy Research. Jakarta: PT. Bumi Aksara Dixon, J. A. (1990). Economics of Protected Areas. Washington DC: Island Press

Dunn, W. N. (1992). Analisia Public Policy (edited by Muhanjir). Yogyakarta: PT. Hananinda Dwipayana, A. (2006). Participatory Rural Renewal. Yogyakarta: Pustaka Belajar Hardiyansyah. (2012). System Administration and Human Resource Management in the Public Sector perspective of regional autonomy. Yogyakarta: Gava Media.

Indiahono, D. (2009). Dynamic Policy-Based Public Policy Analysis. Yogyakarta: PT. Gaya Media.

Islamy, I. (2009). Perummusan pinsip principles of State Policy. Jakarta: PT. Bumi Aksara Jayadinata, J. T. (1999). Land Use in Rural Urban and Regional Planning. Bandung: ITB.

Kencana, S. I. (2006). Public Administration. Jakarta: Rineka Cipta.

Kusumanegara, S. (2009). Models and Actors in the Process of Public Kebijaan. Yogyakarta: Gava Media.

Makmur. (2011). Effectiveness of Institutional Control Policy. Bandung: PT. Refika Aditama. Nugroho, R. (2008). Public Policy. Jakarta: PT. Elex Media Komputindo. http://dx.doi.org/10.3152/030234208X323334

Nurzaman, S. S. (2002). Regional Planning in Indonesia. Bandung: ITB

Santoso, P. (2010). Learning Module - Publlik Policy Analysis. Yogyakarta: browse polotik 


\section{Macrothink}

Journal of Social Science Studies

ISSN 2329-9150 2017, Vol. 4, No. 1

and Government, University of Gajah Mada

Santoso, P. (2006). Participatory Rural Renewal. Yogyakarta: Pustaka Belajar.

Satibi, I. (2011). Thesis Writing Techniques, Tesisi, and Dissertation. Bandung: CAPLAS.

Soemarwoto, O. (1983). Ecology Environment and Development. Jakarta: Djambatan

Suprayogi, S. Y. (2011). Administration Publlik, Concept and Development Studies in Indonesia. Yogyakarta: Pustaka Belajar.

Sujarto, D. (2001). Strategic options, A Decision Making Techniques in City and Regional Planning. Bandung: ITB.

Suryadi, S. (2012). Public Administration and Local Autonomy. Bandung: Prisma Press Prodaktama.

Thoha, M. (2008). Studies of Contemporary Public Administration. Yogyakarta: Kencana Prenada Media Group.

Tuwo, A. (2011). Management of Coastal and Marine Ecotourism. Surabaya: Brilliant International.

Wardiyanto. (2010). Tourism Development Planning. Bandung: Lubuk Agung.

\section{Document:}

Tasikmalaya Regional Regulation No. 2 of 2012 on Spatial Planning of Tasikmalaya Regency 2011-2031.

\section{Copyright Disclaimer}

Copyright for this article is retained by the author(s), with first publication rights granted to the journal.

This is an open-access article distributed under the terms and conditions of the Creative Commons Attribution license (http://creativecommons.org/licenses/by/3.0/). 